\title{
Online Academic Resources With The Focus Of Eye Behaviors*
}

\section{Çevrimiçi Akademik Kaynaklarının Kullanımında Göz Davranışlarının Değerlendirmesi}

\author{
İsmail Çetin ${ }^{1}$ (D), Emine Şendurur ${ }^{2}$ (1)
}

*This submission appeared as part of İsmail Çetin's master thesis, titled "The Determine of Access Problems to Online Academic Resources and Usability Evaluation of Interfaces" with advisor Assoc. Prof. Dr. Emine Sendurur

1(Res. Asst.), Ondokuz Mayıs University, Computer and Department of Instructional Technology Education, Samsun, Turkey

${ }^{2}$ (Assoc. Prof.), Ondokuz Mayıs University, Computer and Department of Instructional Technology Education, Samsun, Turkey

ORCID: İ.C. 0000-0002-7865-6080 E.Ş. 0000-0002-0340-6378

\section{Corresponding author:}

İsmail CETIN

Ondokuz Mayıs Üniversitesi, Bilgisayar ve

Öğretim Teknolojileri Eğitimi Bölümü,

Samsun, Türkiye

E-mail address: ismail.cetin@omu.edu.tr

Submitted: 08.09 .2020

Revision Requested: 30.11 .2020

Last Revision Received: 00.00 .000

Accepted: 09.12.2020

Published Online: 12.03 .2021

Citation: Cetin, I., \& Sendurur, E. (2021). Online academic resources with the focus of eye

behaviors. Acta Infologica 5(1), 13-26.

https://doi.org/10.26650/acin.791978

\begin{abstract}
The aim of this study is to investigate the eye movements of participants during academic searching tasks. Since the Web of Science, Google Scholar, and Council of Higher Education Thesis Center are among the popular academic search platforms in Turkey, we focused on the usability of them. During the preliminary analysis, we explored the most problematic tasks, and then analyzed the eye movements. The problematic tasks were detected with respect to the unexpected differences of completion duration; the failure of completion status; unexpected number of clicks; high number of fixations; high fixation duration; unrelated fixation areas; and think aloud data. Tobii Studio 3.4.2 was utilized for both the collection and analysis of eye-tracking data. 21 academicians participated to the study. The results of the analysis indicated that due to interface design, the eye movements of participants tended to focus on unrelated parts of the screen. As a result, certain parameters of eye tracking demonstrated how participants' eye movements tended to generate intense fixations, increased amount spent for unrelated areas, intense mouse clicks, and increased total amount spent for tasks. In addition to those parameters, users' satisfaction levels showed a decrease as a result of unexpected experiences.
\end{abstract}

Keywords: Usability, Eye Tracking, Eye Movements, Online Search, Online Academic Sources

Öz

$\mathrm{Bu}$ çalışmanın amacı, çevrimiçi akademik kaynak kullanımında göz hareketlerini incelemektir. Bu kapsamda ülkemizde en yaygın kullanıma sahip çevrimiçi akademik kaynaklardan olan Web of Science, Google Akademik (Google Scholar) ve YÖK Tez Merkezi web sitelerinin kullanılabilirlik testi esnasında en çok problem yaşanan görevler belirlenmiş ve kullanıcıların bu görevleri gerçekleştirirken sergilediği göz hareketleri analiz edilmiştir. En çok problem yaşanan görevler, görevlerin tamamlanması gereken süre ile tamamlanma süreleri arasındaki farkın yüksek olmasına, görevlerin tamamlanma durumlarına, fare tıklama sayılarına, sabit bakış sayılarına, sabit bakış sürelerine, sabit bakış yerlerine ve kullanıcı yorumlarına bakılarak belirlenmiştir. Bu işlemler için Tobii Studio 3.4.2 programı kullanılmıştır. Araştırma, çevrimiçi akademik kaynakları kullanma konusunda en az 2 yıl tecrübesi olan 21 akademisyen ile gerçekleştirilmiştir. Çalışmada geçerlilik için veri çeşitlemesi sağlanarak nicel ve nitel veriler birlikte kullanılmıştır. Bulgular sonucunda ara yüz tasarımındaki sıkıntılardan dolayı kullanıcıların yanlış yerlerde ve daha yoğun sabit bakış sergilediği, bu durumun da sabit bakış süreleri, fare tıklama sayıları ve görev tamamlama sürelerini olumsuz etkilediği ve memnuniyetlerini düşürdüğü belirlenmiştir. Bu problemlerin sebepleri incelenmiş ve çözüm için önerilerde bulunulmuştur.

Anahtar kelimeler: Kullanılabilirlik, Göz İzleme, Göz Hareketleri, Çevrimiçi Arama, Çevrimiçi Akademik Kaynaklar 


\section{INTRODUCTION}

The concept of information searching has been transformed into different formats due to rapid changes in electronic and digital sources. In the field of academia, the way to access any information has become easier in comparison to the past. Traditional printed resources have certain limitations. For example, borrowing it from a library may not be possible, but electronic or digital versions are accessible all the time. Searching for specific information within pages can be a challenging task for printed sources, but it is much easier in digital versions. Such different dimensions introduced by e-sources facilitate the effort spent by the researcher as well as the time spent (Kazan, 2017).

Rapidly increasing amounts of online information is expected to reach 35 zettabytes by the end of 2020 (Agrawal \& Nyamful, 2016). Such an imbalanced increase in the electronic world is vulnerable to the quality of the information, i.e. not all information in that world is valid and reliable. Since users deal with different types of user interfaces on the web, experiencing various usability problems is very likely. These problems can result in frustrations for users. System performance such as response time, availability of reliable and valid content, broken or outdated links, and inadequate web search results are some of the things that affect user experience. (Brandt et al., 1996; Kovacs \& Elkordy, 2000; Land, 2000). In addition, the design and usability of user interfaces may affect the way people access and use online information. In typical software, $48 \%$ of codes are related to interfaces (Myers \& Rosson, 1992), which might be a reason why the design of appealing interfaces should be achieved. According to Norman (1988), reducing the possibility of errors is an important mission of any computer programs as well as making the recovery of errors possible. Similarly, in Nielsen's heuristics, the importance of interface designs was also emphasized. Since the online search is important for today's computer users, the usability of available tools is quite important.

Usability as a term is not very easy to define because the measurement of it is considerably hard and sophisticated, and therefore defining it in a scientific framework took time and was not always accepted by everyone (Hertzum et al., 2009). Nevertheless, in daily life, people generally use the semantic meaning of the term rather than the terminological one. For example, in ads, one can come across slogans such as "easy cleaning", "make your life easier", "easy to connect", "friendly screen". These are all examples of using the term in everyday meaning. From its semantic meaning, the term usability can also be expressed in the following terms: "learnability", "easy to use", "user friendly", and "transparent to users" (Cagiltay, 2011).

In the literature, the term usability can also be defined in various ways by different researchers. For example, according to Nielsen (2012), usability is a qualified indicator showing how easy to use a system is in addition to consisting of methods for designing usable systems. Shackel (2009) defines usability as the ability to complete the given tasks easily and effectively within the given scenario providing support. In the International Organization for Standardization (ISO) standards book, usability is located into two different parts. In the ISO 9241-11 (2018) part, the definition focuses on effectiveness, efficiency, and satisfaction within a context. In the ISO/IEC 2510 (2011) part that covers a wide range of computer related systems, the usability is associated with quality within effectiveness, efficiency, satisfaction, freedom from risk, and context coverage characteristics.

Although there are clearly defined standards, the usability testing is not very easy to pursue because there are lots of elements to be considered. Technical problems, calibration problems and ethical principles are some of these elements. The usability tests can be designed upon users, experts, models, and design principles. Each approach has its own advantages and disadvantages. Moreover, utilizing different test methods can generate varying results (Cagiltay, 2011). One of these approaches is Eye-tracking methodology. This technique is a system that determines eye movements and focus areas of the eye (Almedia et al. 2011). Eye-tracking methodology is a relatively objective technique used to collect data for user testing. As the user interacts with the interface, his/her fixations can be viewed through this technique in a detailed way (Nakatani \& Pollatsek 2004; Renshaw \& Webb 2006; Scheiter \& Van Gog 2009). Such a technique enables the researchers and designers to diagnose the errors, misunderstandings, misguidance, and the most attractive locations on the screen (Pernice \& Nielsen, 2009). Moreover, the researchers or designers can save time by locating the exact issues related to usability. 
There are various studies investigating usability through the utilization of eye trackers. University web sites, e-libraries, governmental sites, handbooks, educational multimedia environments, and online academic resources have been the popular environments for usability studies. As a result of those, the researchers revealed many practical implications including misguiding buttons, links, colors, and so on (Alemdag \& Cagiltay 2018; Cetin \& Sendurur, 2016; Lund, 2016; Yavuz et al. 2016; White, 2016). Eye tracking is a technique that has been used in many different areas of research other than usability. Factors affecting web visits, the effects of visuals on online reading performance, behavior of children using the Internet, web searching behavior and the quality of online ads are some of the other areas in which eye tracking is used(Beymer et al., 2007; Buscher et al., 2010; Byerly, 2007; Cutrell \& Guan, 2007; Pan et al., 2004). In addition, the eye tracking technique has been used to examine the cognitive process of users on search engine results pages (Lewandowski et al., 2018).

Scholars and graduate students generally use online academic resources due to their convenience of accessibility and coverage. Instead of searching among hardcopies of journals, searching with the help of e-databases, search engines, etc. is more convenient for many researchers. Unlike general purpose online tools like Google search engine, the online academic tools have specific user profiles, which are scholars. Nevertheless, the design of interfaces can hinder the search process. In the literature, there are many usability studies, but they are mostly limited with library resources. In order to provide guidance with the designers as well as publishers, this study aims to fill the gap with a specific focus of comparing the usability of three popular online academic resources in a qualitative way: Web of Science, Google Scholar, and National Thesis Center (NTS). The main research question of the study is as follows:

RQ: How do users' eye behaviors change when the design of the interface has some usability problems?

\section{METHOD}

The research design of this study follows the simultaneous mixed methodology (Tashakkori and Teddlie 1998). During the user test sessions, both qualitative and quantitative data were collected, and then they were analyzed and interpreted in a complementary manner. Table 1 summarizes the design.

Table 1

Research design

\begin{tabular}{ll}
\hline Data Collection Method & Data Analysis Method \\
\hline Eye Tracking Record & $\begin{array}{l}\text { Quan - Descriptive Statistics (Tobii Studio 3.4.2) } \\
\text { Qual - Content Analysis }\end{array}$ \\
Observation Form & Qual - Content Analysis \\
Satisfaction Form & Qual - Content Analysis \\
\hline
\end{tabular}

\subsection{Participants}

In this study, the convenient sampling method was used to select participants because they have to travel to the humancomputer interaction laboratory, and spend time for the session. The participants of this study were selected according to their experience on using online academic resources because the interface should be familiar to the users (Dumash and Redish 1999). The subject area of researchers varied. According to Virzi (1992), 5 participants are enough for user tests. However, researchers like Lindgaard and Chattratichart (2007) were against this idea. Nielsen and Landauer (1993), on the other hand, made a classification depending on the scale of the research, and claimed that 7-15 could sometimes reveal the majority of the errors. In reference to Nielsen and Landauer (1993), we included 21 users in this study. 9 of them were male, and 12 of them were female. Detailed demographics were presented in Table 2. 
Table 2

Demographics of Participants

\begin{tabular}{lll}
\hline & $\mathbf{n}$ & \% \\
\hline Gender & 12 & 57.1 \\
Female & 9 & 42.9 \\
Male & & \\
Age & 9 & 42.9 \\
$23-27$ & 7 & 33.3 \\
$28-32$ & 5 & 23.8 \\
$33-38$ & & \\
Experience of Online Academic Resources & 10 & 47.7 \\
$2-3$ years & 9 & 42.9 \\
$5-6$ & 2 & 9.4 \\
$7-10$ & & \\
Department & 5 & 23.9 \\
Civil Engineering & 5 & \\
Computer Education \& Instructional Technologies & 4 & 19 \\
Industrial Engineering & 4 & \\
Electronic \& Electrical Eng. & 3 & 9.5 \\
Chemistry & 2 & 9.5 \\
Computer Engineering & 2 & 9.5 \\
Geography & 2 & 9.5 \\
Informatics & 2 & 4.9 \\
\hline
\end{tabular}

\subsection{Instruments \& Apparatus}

Before deciding on the tasks to be included in the experiment, the researchers talked to and observed the scholars around them. As a result of those unstructured and informal interviews, a group of frequently performed tasks emerged and formed the boundaries of our user tests. Finding a specific publication of a scholar, ordering the publications with regards to given criteria, and accessing dissertations published on a given date were the initial tasks that we aimed to include. In order to decide on the online academic resources, we delivered a questionnaire (Author(s), 2016). In the survey study, users were asked about the online academic resources they use most frequently, the reasons for choosing this resource, and the most common problems they encounter while accessing these resources. Since the detailed results are not the main concern of this study, the detailed qualitative analysis of user experience of hard tasks is the emphasis of the current study. In a preliminary study, Author(s) (2016) explored that the following two tasks were the most complicated ones according to users, and the analysis of eye movement approved that claim which is why this study has a deep focus on the following two tasks:

Task 1: List the studies of which title includes "instructional design” keywords.

Task 2: Download the dissertation written by “* (removed for blind review)”.

The tasks were the main instruments, but in order to observe and record data, Tobii Studio 3.4.2 was utilized as another instrument. Tobii Studio is an eye-tracking platform for the recording and analysis of eye gaze data. In addition to screen recordings, participants' voice recordings were also important for gaining insights into what they were thinking as they moved on. There was a Tobii T120 eye tracker with 0.5 degree of sensitivity integrated into the desktop with a 17 -inch monitor. The screen resolution was $1024 \times 768$ during data collection. The room was surrounded by cameras to record gestures and mimics. The participants were given wearable microphones for voice recording. The chair was adjustable and thus the height variety of participants was not a problem. Although certain head movements were tolerated by the eye tracker, we advised participants to keep an approximate $60 \mathrm{~cm}$ distance from the tracker (Tobii Studio 2008). 


\subsection{Data collection \& analysis}

Before starting the test, the users were informed about the procedure and ethical issues. They were free to stop, leave or have a break whenever they wanted. Then, the tasks were given in a written format and stayed in front of them during the test. The calibration was run for each participant to increase the reliability of recordings. 9 point calibration was conducted. The author(s) did not intervene in the sessions, i.e. users were encouraged to perform as if they were at home/library/office. They were also encouraged to think aloud. An average session took about 45 minutes. The users were expected to complete each task separately. No stimulus was presented at the beginning. In the beginning of the experiment the web browser was ready to be used. At the end of each session, users were asked to complete the satisfaction questions. The experiment was implemented in a public university's human-computer interaction laboratory.

The usability criteria consist of three facets: effectiveness, efficiency, and satisfaction. In order to evaluate the effectiveness of the chosen academic resources, we focused on the completion status of tasks and tried to investigate the reasons for failure. Efficiency in the current user test was decided according to the following metrics: time to first fixation, first fixation duration, total fixation duration, fixation count, time to first mouse click, time from first fixation to next mouse click, and mouse click count. For the third dimension, satisfaction, we assigned each user a satisfaction questionnaire after the test. All data were analyzed with the combination of both qualitative and quantitative analysis methods. Tobii Studio 3.4.2 program mostly benefited from quantitative analysis. Think aloud data, observation notes, and satisfaction questionnaires were analyzed in a qualitative way utilizing content analysis techniques. At the end of the analysis, the researchers diagnosed the two tasks that were perceived as the most difficult ones. As a result, the eye movements of users were closely analyzed in this part of the study.

\section{RESULTS}

When deciding on the most problematic tasks to be included in this study, we focused on the gap between expected and observed task completion duration, the task completion status, number of mouse clicks and fixations, fixation durations and locations as well as user comments. We examined gaze plots of users for detailed eye movements. As a result of that preliminary analysis, we decided to include two tasks, which seemed problematic.

The critical screen parts, i.e. the related areas leading to the completion of tasks, consisted of areas of interest (AOI) in this study. In the first task, locating and clicking the detailed search menu was a critical action for the task completion. In the second task, locating where to download the dissertation was an important phase. That's why the menu area was signed as an AOI, and the eye movements to the first fixation to that AOI was analyzed in detail. Table 3 summarized the metrics of those two tasks. Table 4 includes metrics of eye movements: time to first fixation to the target AOI, number of fixations on the AOI, and time to first mouse click on the AOI.

Table 3

Expected vs. Found Results

\begin{tabular}{|c|c|c|c|c|c|c|c|c|}
\hline Tasks & Average TCD* & Shortest TCD* & $\begin{array}{c}\text { Longest } \\
\text { TCD* }\end{array}$ & Expected TCD* & Average MC\# & $\begin{array}{l}\text { Min } \\
\text { MC\# }\end{array}$ & $\begin{array}{l}\text { Max } \\
\text { MC\# }\end{array}$ & Expected MC\# \\
\hline Task 1 & 60.88 & 25 & 154 & 16 & 8 & 5 & 11 & 4 \\
\hline Task 2 & 52.9 & 13 & 126 & 15 & 8.5 & 7 & 15 & 6 \\
\hline
\end{tabular}

*TCD: Task Completion Duration; \#Mouse Clicks

Table 4

Average Fixations and Mouse Clicks

\begin{tabular}{lccc}
\hline Tasks & Time to First Fixation & Number of Fixations & Time to First Mouse Click \\
\hline Task 1 & 9.81 & 11.06 & 8.58 \\
Task 2 & 4.03 & 81.10 & 5.39 \\
\hline
\end{tabular}


The expected ones in Table 3 represent the optimum possible way to follow. For instance, one can complete the Task1 with 4 mouse clicks, but there is a considerable difference between minimum and maximum number of clicks, which may be a sign of the design problem. Similarly, task completion duration for this task takes about 16 seconds, however, the gap between participants' performance was striking. For example, one user completed it in 25 seconds, which is close to the expected one, whereas another user finished in 154 seconds. In addition, the average task completion duration is approximately four times longer than the expected duration. Therefore, this task is a good candidate for deep focus with regards to eye movements. Most of the users explained how they had difficulties finding the detailed search option. Most of the participants failed to complete the task, and therefore gave up. As shown in Table 4, users fixated on the related AOI, but it took about 8.58 seconds to associate it with the target task and to click on it. The following excerpts exemplifies the satisfaction status of users:

"...detailed search cannot be found. I thought that keywords of previous searches would appear when I click the arrow sign." (K4)

“... I think finding detailed search is hard for beginners.” (K5)

"It would be better if there is a hint for a detailed search option." (K13)

"I really had difficulty finding the detailed search. The location of it does not make any sense. I wouldn't think that it would be there." (K16)

“...there are no visuals of detailed search, I couldn't have completed the task.” (K20)

In the second task, users were expected to search and download the given dissertation. All users found it, but there were gaps between expected and performed values of metrics. The average task completion duration was 52.9 seconds, which is above the expected duration. Moreover, the shortest duration was almost ten times shorter than the longest task completion duration. Besides the large gap among the performances of the users, the number of mouse clicks was above expectations. There were too many fixations $(\mathrm{N}=81)$ on the target AOI, whereas it took 5.39 seconds to detect and decide to click. According to users, the link did not seem to be clickable, and therefore they hesitated, which brought about a longer task completion period. The following excerpt are some examples of users' hesitations:

"Downloading the dissertation was very difficult. I found it incidental , I clicked the first clickable place and downloaded." (K1)

“...there was neither a hand sign nor any other sign to guide the downloadable area. I worked hard to find the location of the dissertation to download." (K6)

"I found the dissertation, but the button was hardly visible. One needs to click the dissertation number to download. Incidentally, I clicked hoping that would be the right link." (K19)

The Fastest vs. Slowest Users' Eye Movements for Task 1: Examining the task completion processes of all users showed difficulties in finding the detailed search option. An average user can complete the task in about 16 seconds. In this study, the fastest duration was recorded as 25 seconds (K12). The gaze plot of user K12 was demonstrated on Figure 1. It can be observed that the user detected the related field of the screen after a few fixations over the top left corner of the screen. On the other hand, the longest duration was recorded as 154 seconds (K1). Since user K1 did not detect the menu part for the detailed search, s/he first did a regular search, and then tried to access the detailed search menu on the results page, which brought about a longer task duration. Figure 2 demonstrates the heat-map of K1. 


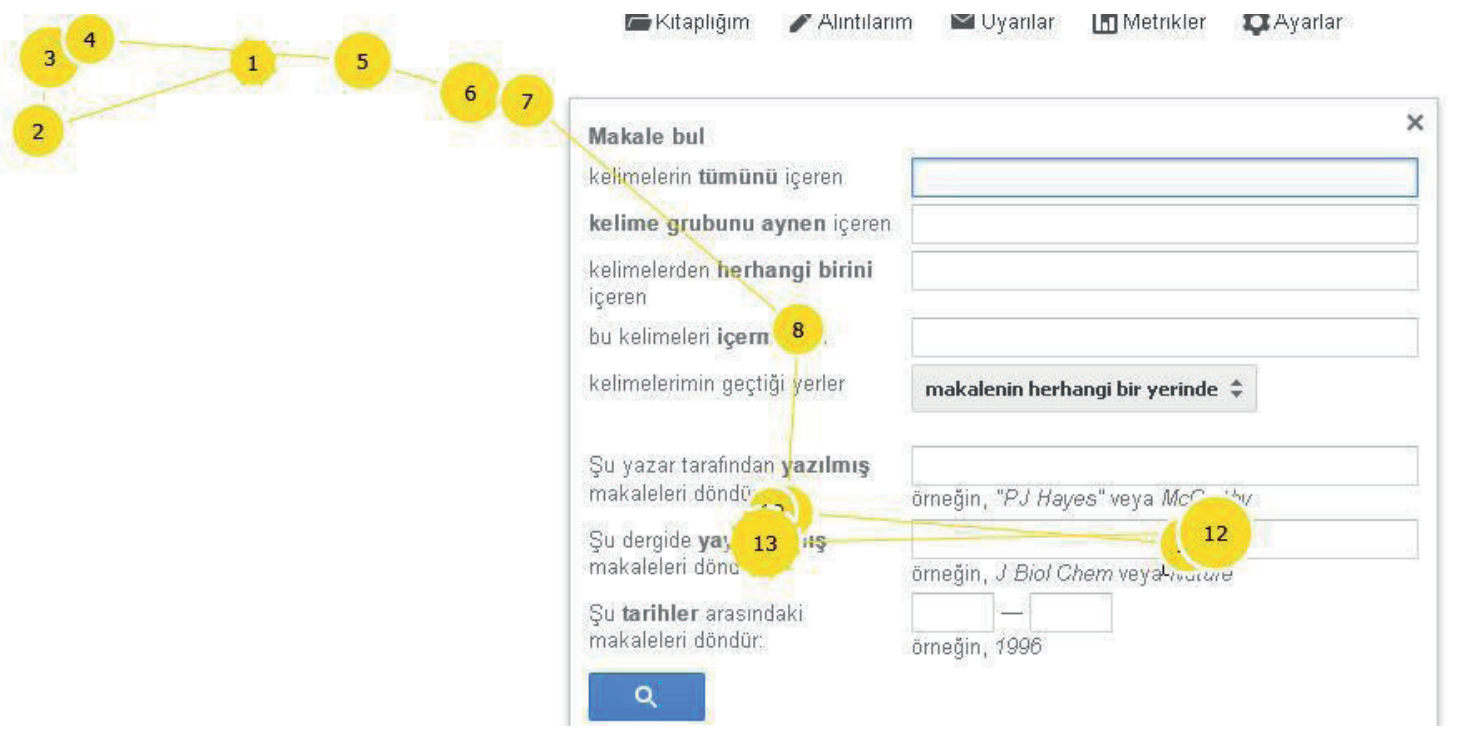

Figure 1. The gaze plot of K12 during Task 1

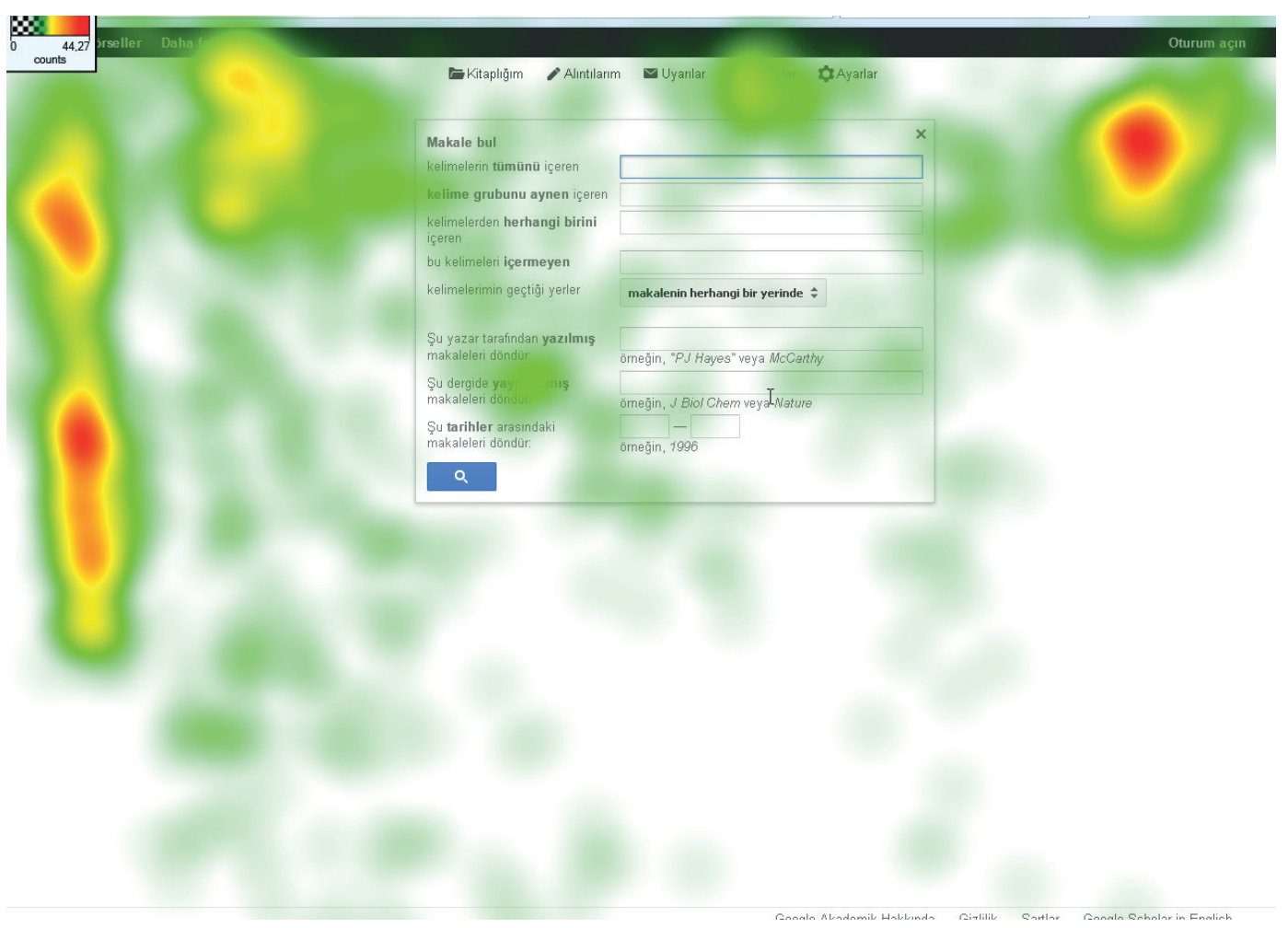

Figure 2. Gaze plot of K1 during Task 1

User K1 spent a considerable amount of time on the left side of the page, then skimmed all pages around, and then due to the lack of hints, s/he focused on the article links on the results page for a detailed search tool. Finally, despite fixations on the target area, s/he did not locate/click the item. After spending too much time, s/he went back to the main search page and found the detailed search tab. In short, realizing the existence of the option took about 103 seconds, which is quite long. As pop-up appeared, user K1' s examining the window, writing keywords, and searching processes took 51 seconds, which is still longer than the shortest task completion duration. Figure 3 shows the first 7 seconds of user K1, after pop-up windows. 
14

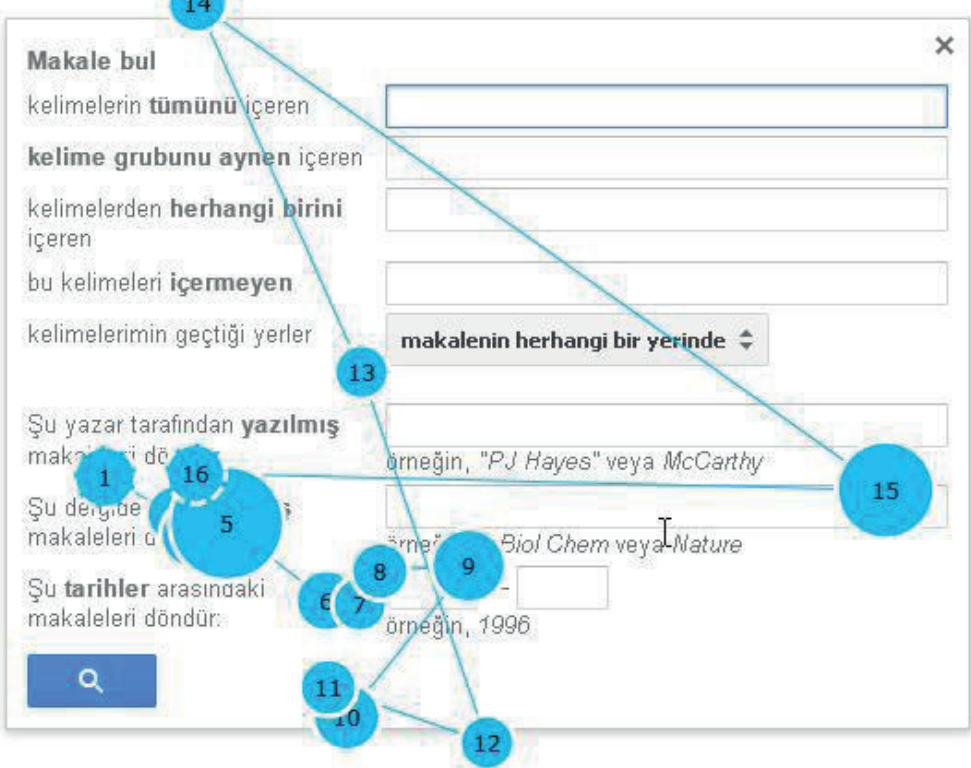

Figure 3. The first 7 seconds of K1 on Task 1

Failures of Task 1: Users K13, K16, and K20 were not able to finish Task 1. The eye movements of those users show intense fixations on the menus on both sides of the page. User K13 spent too much time focusing on the interval option of the menu, but as soon as realizing the date specific facet of that part, s/he shifted the focus. Like user K13, user K16 tried to find the detailed search on the both sides of the page . Despite shorter fixations, K16 spent too much time locating the correct menu item. Although s/he saw the item on the settings button at the upper right corner, $\mathrm{s} / \mathrm{he}$ did not associate it with the task, and thus failed to complete. The longest fixations of that user were also on the target area. User K20 showed short fixations all around the page, but could not have realized the target, and as a result of that $\mathrm{s} /$ he gave up the task. Figure 4 consists of the eye movements of users who failed during Task 1.

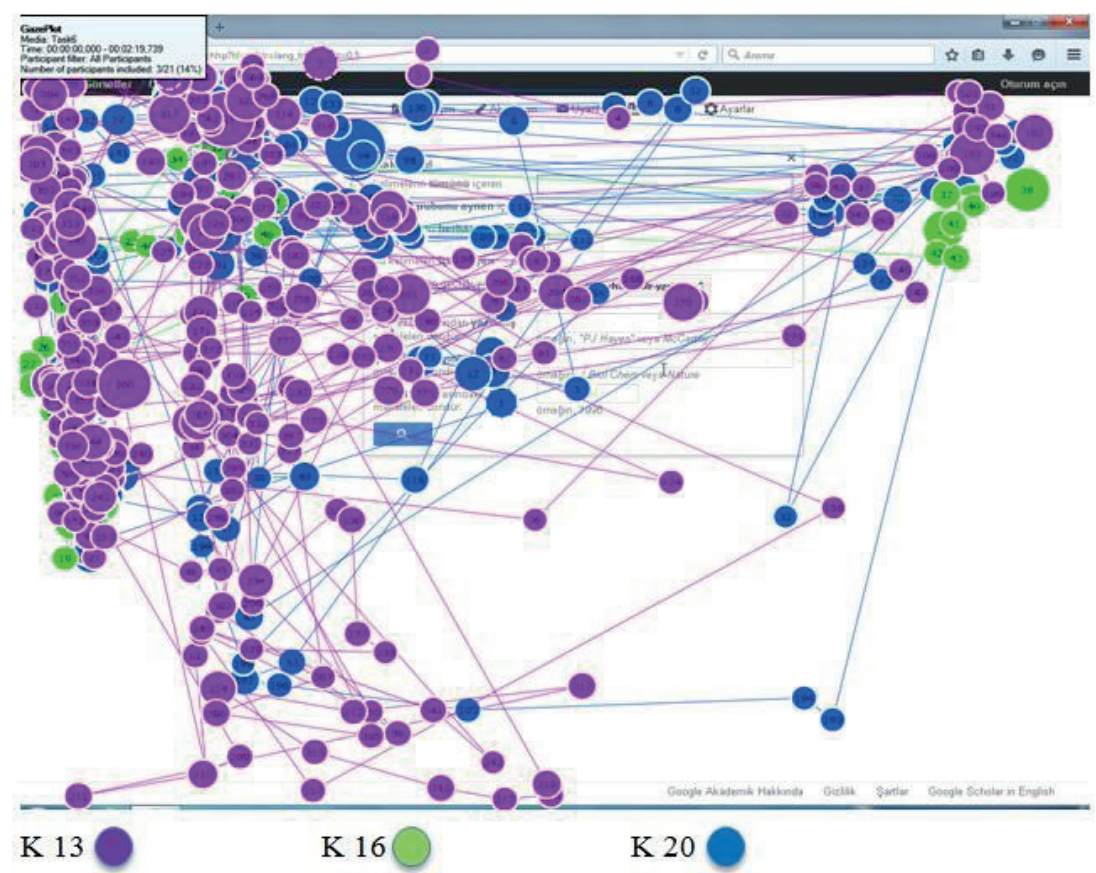

Figure 4. Eye movements of users who gave up the Task 1 
The Fastest vs. Slowest Users' Eye Movements for Task 2: An average user can complete the task at about 15 seconds, but one of the participants (K9) was faster with 13 seconds. The slower performers generally got stuck on finding the download link. User K9 first entered the keywords on the main page with necessary options. Once realizing the dissertation number, $\mathrm{s} /$ he clicked and the downloading process started. That user had slight fixations on general information about the thesis, and never got distracted by other items on the page. Figure 5 shows smooth eye movements of the user.

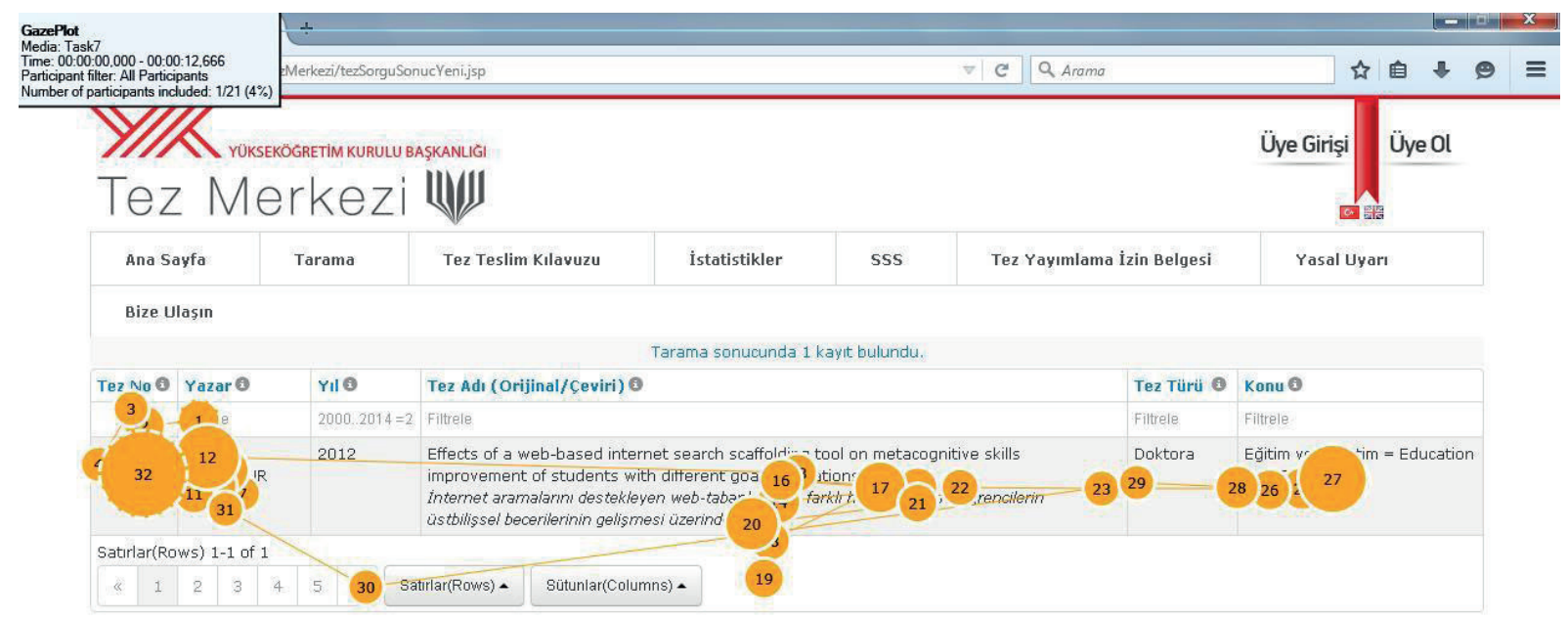

Figure 5. Gaze plot of user K9 during Task 2

User K11 completed Task 2 within 109 seconds. As shown on Figure 6, s/he gazed around all over the page, fixated and clicked each item one by one. Despite frequent fixations on that area, s/he did not click on the dissertation number, which was the target area for downloading. It can be observed that the duration of fixations on that area increased towards the end of the task. As the user was sure of the functions of other items, s/he decided to click on the correct link. Figure 7 shows the first 6 seconds of the user. According to eye movements on that figure, s/he did not fixate on the correct place for 5 seconds. After 6 seconds, s/he fixated on the right item, but did not click.

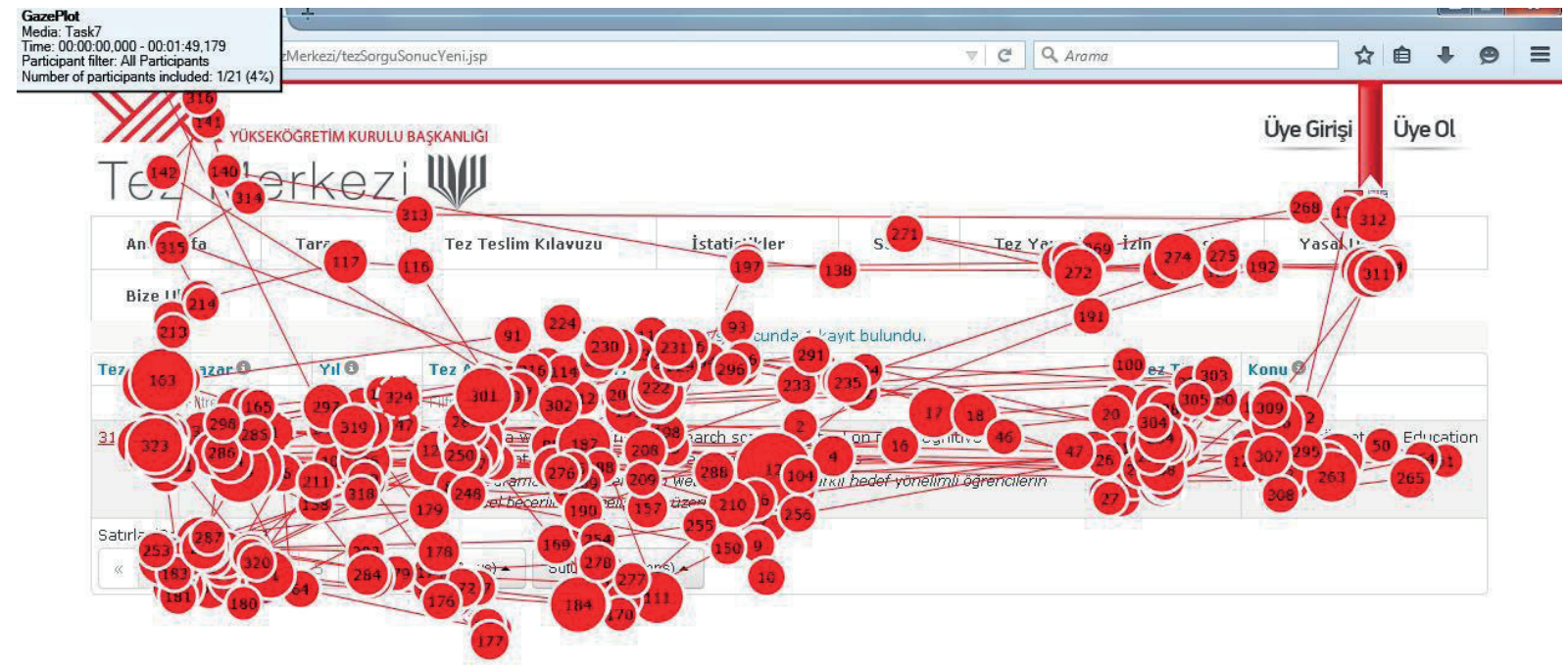

Figure 6. Gaze plot of user K11 during Task 2 


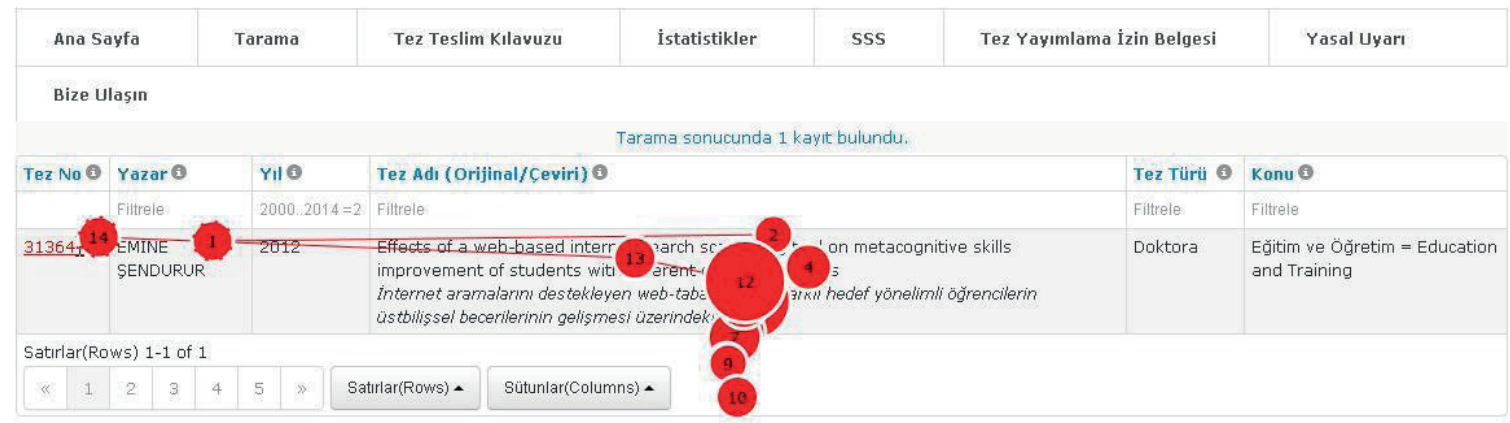

Figure 7. The first 6 seconds of K11 on Task 2

Failure of Task 2: There was only one user who failed to complete the task (K1). The search patterns of K1 were very similar to K11, the slowest user in Task 2. User K1 gazed all around the page with similar fixation durations, and fixated on the dissertation number, but did not click due to lack of associations with the download link. As a result, s/he gave up the task. Figure 8 demonstrates the eye movements of the user during Task 2.

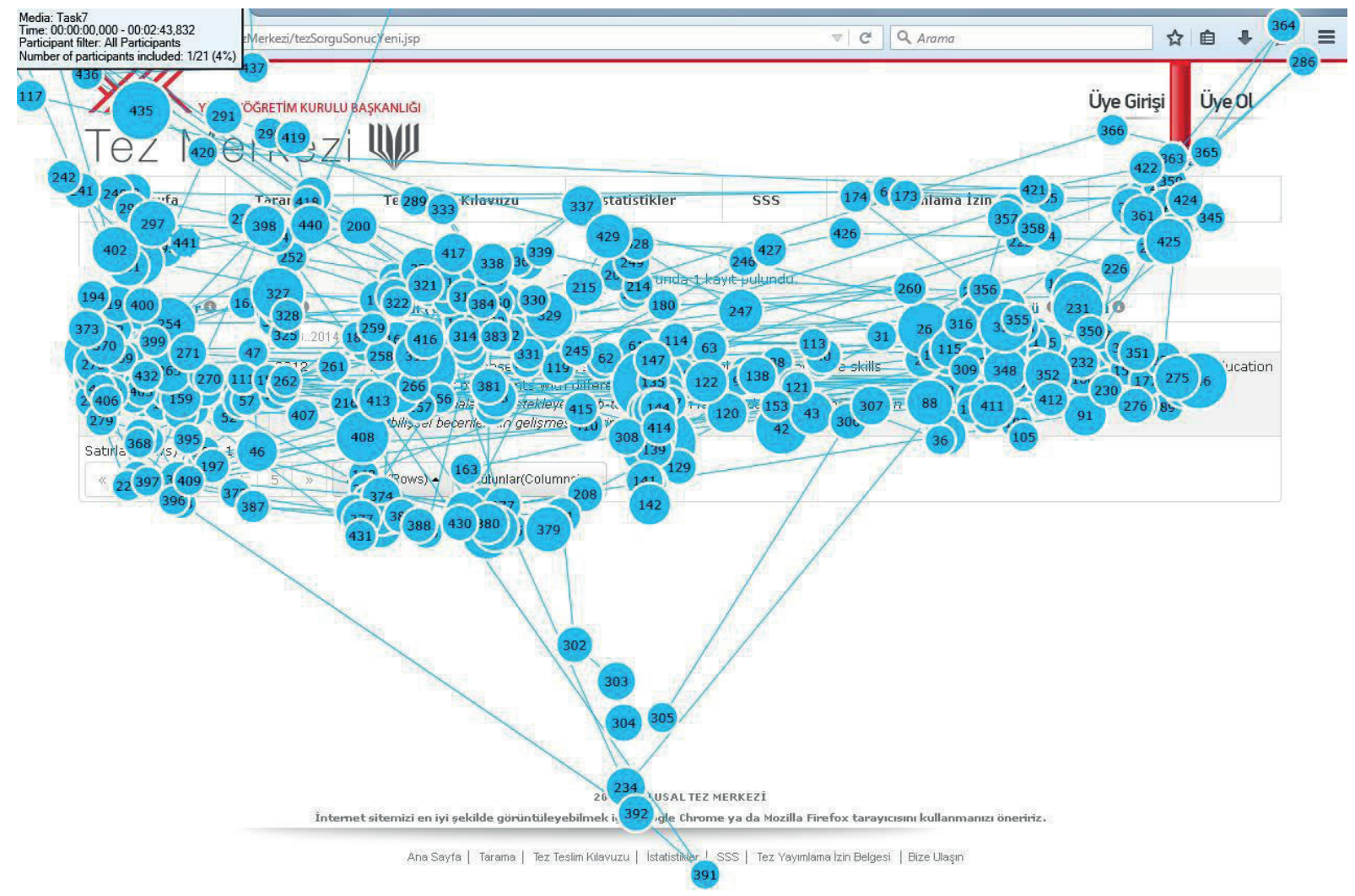

Figure 8. Gaze plot of K1 during Task 2

\section{DISCUSSION AND CONCLUSION}

It was observed that users' gaze plots, efforts to complete the tasks, and task completion durations/status were very different from each other during the two tasks, which caused problematic user experience. In both tasks, users generally focused on both sides of the pages, where menu items are located. Although the majority of the users showed fixations at the correct places, they kept searching for the target at different parts of the screen due to lack of associations. This situation led to 
increases in fixation counts, fixation durations, mouse clicks, and task completion durations. According to Rayner (1998), long fixation durations are associated with intense cognitive effort along with longer thinking durations. This assumption can explain the relation between long fixation durations and task completion duration. In addition, the failure of completion may also be related to cognitive overload as a result of longer fixations everywhere accompanied by mouse clicks. Situations having too many options can cause confusion, which can be a sign of cognitive overload (Murray 2001). For example, the study conducted by Kilic and Karadeniz (2004) indicated that students, whose cognitive load is high, showed lower performance and longer task completion durations in hypermedia. The current study showed that when the user fails to associate the target design element, the number of fixations and mouse clicks increase, and thus the gaze plots exemplify the cognitive overload resulting in either failure or longer task completion durations.

In the first task, users were assigned the task of making a detailed search on Scholar Google. Users generally tended to focus on menu items, but failed to locate the targeted one. Providing users with flexible interfaces including freedom of choices is an important part for usable designs (Nielsen 1994). Although the experienced users accessed the detailed search quickly, the users who rarely used the details option had difficulties learning where to click. In the second task, the main problem was the lack of cues about the existence of a download link, which can be overcome easily by defining the cursor hover style as a pointer. According to Nielsen's (1994) heuristics, consistency and standards should be taken into account for universal designs. In this way, the designer can prevent misconceptions in the interface. In conclusion, the problems in the design of two frequently used online resources resulted in negative user experiences. The users spent extra time and effort due to lack of salient hints. The signals and cues are valuable in increasing the efficiency in learning (Clark et al. 2006).

Finally, the study has limitations in terms of certain issues, and therefore one should be careful when interpreting the results of this study. First, the experiment is limited to assigned tasks. Because of the location of the human-computer interaction lab, we only included the volunteers who were available around us in the study. In the beginning protocol, we encouraged users to behave as if they were at home/office, but being in a controlled environment may have affected the overall performance of the users.

The research implications can be summarized as follows:

- Since we utilized convenient sampling, the further studies can enlarge the number and variety of participants.

- One can provide alternative designs and compare them with the old ones.

- One can compare the resources based on the participants' age or gender.

- The practical implications can be summarized as follows:

- Before eye tracking experiments, the researcher should make sure the physical and technical settings are all in good condition.

- Having a plan-B is needed when planning data collection period, because the logistic issues may sometimes restrict the number of accessible users. Scheduling according to users, and having extra users in advance may prevent possible data collection problems.

- Large data size can bring about freezing screens or slow performance. In order to have optimum performance, the software enabling the analysis of eye tracker data should be installed on a high performance computer.

- In user tests, data collection with eye trackers is a considerably lengthy process, that's why time management and planning is necessary to increase efficiency. 
Hakem Değerlendirmesi: Dış bağımsız.

Çıkar Çatışması: Yazarlar çıkar çatışması bildirmemiştir.

Finansal Destek: Bu çalışma, Ondokuz Mayıs Üniversitesi Bilimsel Araştırmalar Proje Birimi (BAP) tarafından desteklenmiştir. (Proje No: PYO.EGF.1904.15.005)

Peer-review: Externally peer-reviewed.

Conflict of Interest: The authors have no conflict of interest to declare.

Grant Support: This research was supported by Ondokuz May1s University BAP. (Project number: PYO.EGF.1904.15.005)

\section{Kaynaklar/References}

Agrawal, R., \& Nyamful, C. (2016). Challenges of big data storage and management. Global Journal of Information Technology, 6(1), 1-10. https://doi. org/10.18844/gjit.v6i1.383

Alemdag, E., \& Cagiltay, K. (2018). A systematic review of eye tracking research on multimedia learning. Computers \& Education, 125, 413-428. http:// doi.org/10.1016/j.compedu.2018.06.023

Almeida, S., Veloso, A., Roque, L., \& Mealha, O. (2011, January). The Eyes And Games: A Survey Of Visual Attention. In The Sbgames Brazilian Symposium On Computer Games And Digital Entertainment. Salvador, Brazil,

Bahsisoglu, H. K. (2006). E-kaynaklar kullanımının akademik çalışmalara sağladı̆̆ı kolaylıklar. Akademik Bilişim Bilgi Tek IV 9-11. http://ab.org.tr/ ab06/bildiri/133.doc. Accessed 05 May 2019

Beymer, D., Orton, P. Z., \& Russell, D. M. (2007, September). An eye tracking study of how pictures influence online reading. In IFIP Conference on Human Computer Interaction Springer Berlin Heidelberg 2007 (pp. 456-460). Springer, Berlin, Heidelberg.

Brandt, D. S. (1996). Evaluating information on the internet. Computers in Libraries, 16(5), 44-46.

Buscher, G., Dumais, S. T., \& Cutrell, E. (2010, July). The good, the bad, and the random: an eye-tracking study of ad quality in web search. In 33rd international ACM SIGIR conference on Research and development in information retrieval 2010 (pp. 42-49). https://doi.org/10.1145/1835449.1835459

Byerly, G. (2007). Look in their eyes-eye tracking, usability, and children. School Library Media Activities Monthly, 23(8), 30-32.

Clark, R. C., Nguyen, F., Sweller, J., \& Baddeley, M. (2006). Efficiency in learning: Evidence-based guidelines to manage cognitive load. Performance Improvement, 45(9), 46-47. http://doi.org/10.1002/pfi.4930450920

Cutrell, E., \& Guan, Z. (2007) What are you looking for?: an eye-tracking study of information usage in web search. In: SIGCHI conference on Human factors in computing systems (pp. 407-416). https://doi.org/10.1145/1240624.1240690

Çagiltay, K. (2011). Insan bilgisayar etkileşimi ve kullanılabilirlik mühendisliği: Teoriden pratiğe. ODTÜ Yayıncılık, Ankara

Cetin, I., \& Sendurur, E. (2016). Çevrimiçi akademik kaynakların kullanılabilirlik değerlendirmesi. Mehmet Akif Ersoy Üniversitesi Eğitim Fakültesi Dergisi, 1(40), 273-299. http://doi.org/10.21764/efd.04062

Dumas, J. S., \& Redish, J. (1999). A practical guide to usability testing. Intellect Books.

Hertzum, M., Hansen, K. D., \& Andersen, H. H. (2009). Scrutinising usability evaluation:does thinking aloud affect behaviour and mental workload?. Behaviour \& Information Technology, 28(2), 165-181. https://doi.org/10.1080/01449290701773842

ISO 9241-11 (2018). Ergonomic requirements for office work with visual display terminals (vdts) part 11: Guidance on usability. International Organization for Standardization, Geneva. https://www.iso.org/obp/ui/\#iso:std:iso:9241:-11:ed-2:v1:en. Accessed 15 March 2019

ISO/IEC 25010 (2011). Systems and software engineering - systems and software quality requirements and evaluation - system and software quality models. International Organization for Standardization, Geneva. https://www.iso.org/obp/ui/\#iso:std:iso-iec:25010:ed-1:v1:en. Accessed 15 March 2019

Kazan, H. (2017). Avantajları ve dezavantajları ile dijital dergicilik. The Turkish Online Journal of Design, Art and Communication, 7(1), 17-24.

Kilic, E., \& Karadeniz, S. (2004). Hiper ortamlarda öğrencilerin bilişsel yüklenme ve kaybolma düzeylerinin belirlenmesi. Kuram ve Uygulamada Egitim Yönetimi Dergisi, 10(4), 562-579.

Kovacs, D. K., \& Elkordy, A. (2000). Collection development in cyberspace: building an electronic library collection. Library Hi Tech, 18(4), 335-361. https://doi.org/10.1108/07378830010360446

Land, S. M. (2000). Cognitive requirements for learning with open-ended learning environments. Educational Technology Research and Development, 48(3), 61-78. https://doi.org/10.1007/BF02319858

Lewandowski, D., Kerkmann, F., Rümmele, S., \& Sünkler, S. (2018). An empirical investigation on search engine ad disclosure. Journal of the Association for Information Science and Technology, 69(3), 420-437. http://doi.org/10.1002/asi.23963

Lindgaard, G., \& Chattratichart, J. (2007). Usability testing: what have we overlooked?. In Proceedings of the SIGCHI Conference on Human factors in Computing Systems (pp. 1415-1424). ACM. https://doi.org/10.1145/1240624.1240839

Lund, H. (2016). Eye tracking in library and information science: A literature review. Library Hi Tech, 34(4), 585-614. http://doi.org/10.1108/ LHT-07-2016-0085

Murray, T. (2001, October). Characteristics and Affordances of Adaptive Hyperbooks. In WebNet (pp. 899-904).

Myers, B. A., \& Rosson, M. B. (1992, May). Survey on user interface programming. In Proceedings of the SIGCHI conference on Human factors in computing systems (pp. 195-202). ACM. 
Nakatani, C., \& Pollatsek, A. (2004). An eye movement analysis of “mental rotation” of simple scenes. Perception \& psychophysics, 66(7), $1227-1245$. https://doi.org/10.3758/BF03196848

Nielsen, J. (1994). Heuristic evaluation. In Nielsen, J., and Mack, R.L. (Eds.), Usability Inspection Methods, (413-414). John Wiley \& Sons, New York, NY.

Nielsen, J. (2012). Usability 101: Introduction to usability. https://www.nngroup.com/articles/usability-101-introduction-to-usability/. Accessed 21 January 2019

Nielsen, J., \& Landauer, T. K. (1993). A mathematical model of the finding of usability problems. In Proceedings of the INTERACT'93 and CHI'93 conference on Human factors in computing systems (pp. 206-213). ACM.

Norman, D. A. (1988). Designing everyday things. Currency-Doubleday, New York.

Pan, B., Hembrooke, H. A., Gay, G. K., Granka, L. A., Feusner, M. K., \& Newman, J. K. (2004, March). The determinants of web page viewing behavior: an eye tracking study. In Proceedings of the 2004 symposium on Eye tracking research \& applications (pp. 147-154). ACM.

Pernice, K., \& Nielsen, J. (2009). Eyetracking methodology: How to conduct and evaluate usability studies using eyetracking. Berkeley: New Riders Press.

Rayner, K. (1998). Eye movements in reading and information processing: 20 years of research. Psychological bulletin, 124(3), 371-422. https://doi. org/10.1037/0033-2909.124.3.372

Renshaw, J. A., \& Webb, N. (2007). Eye tracking in practice. In 21st British HCI Group Annual Conference University of Lancaster, UK (pp. 239-241). http://doi.org/10.14236/ewic/HCI2007.41

Scheiter, K., \& Van Gog, T. (2009). Using eye tracking in applied research to study and stimulate the processing of information from multi-representational sources. Applied Cognitive Psychology, 23(9), 1209-1214. http://doi.org/10.1002/acp.1524

Shackel, B. (2009). Usability-Context, framework, definition, design and evaluation. Interacting with Computers, 21(5-6), 339-346.

Tashakkori, A., \& Teddlie, C. (1998). Mixed methodology: Combining qualitative and quantitative approaches. Sage.

Tobii Studio (2008) Tobii Studio 1.2 User Manual. https://manualzz.com/doc/4199338/tobii-studio-1.2-user-manual. Accessed 16 September 2018

Virzi, R. A. (1992). Refining the test phase of usability evaluation: How many subjects is enough?. Human Factors: The Journal of the Human Factors and Ergonomics Society, 34(4), 457-468. https://doi.org/10.1177/001872089203400407

White, R. W. (2016). Interactions with Search Systems. New York: Cambridge University Press.

Yavuz, I., Cinar, N. O., \& Cagiltay, K. (2016). Kamu internet sitelerinde yer alan arama alanlarının kullanılabilirliği ve buna yönelik kullanıcı davranışlarının belirlenmesi. International Journal of Informatics Technologies, 9(1), 41. http://doi.org/ 10.17671/btd.81715 
